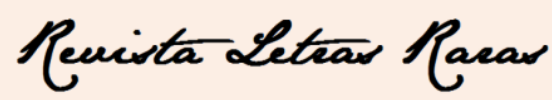

ISSN: 2317-2347 - Vol. 5, Ano 5, № 2 - 2016

\title{
Os elementos apolíneo e dionisíaco e seus desdobramentos no filme Anticristo: uma leitura possível
}

Felipe Freitag ${ }^{1}$

\begin{abstract}
Resumo: O que se pretende nesse trabalho é construir um itinerário de pares de oposição nas cenas e no discurso do filme Anticristo, mapeando os campos semânticos em suas simbologias contrastivas. Para tanto, delinear-se-á uma leitura possível de relações do filme em questão como uma representação das ideias de Friedrich Nietzsche nas obras $O$ nascimento da tragédia e $A$ visão dionisíaca do mundo e como representação das ideias de Camille Paglia na obra Personas Sexuais. Desse modo, serão destacados, no filme Anticristo, a duplicidade dos elementos apolíneos e dionisíacos e seus desdobramentos através das obras supracitadas de Nietzsche, e serão destacadas as relações entre feminino e masculino, natureza bela e natureza daimônica meio da obra sobredita de Paglia. Destaca-se, sobretudo, a importância de investigar a estrutura social presentificada na e pela linguagem, seja ela fílmica, literária, ou cotidiana, de maneira a evidenciar a relação entre palavra e mundo.
\end{abstract}

Palavras-chave: Linguagens. Apolíneo e Dionisíaco. Feminino e Masculino. Natureza bela e Natureza daimônica.

\section{The elements apollonian and dionysian and developmentes in your Antichrist: reading possible}

\begin{abstract}
The aim in this work is to build an itinerary of opposing pairs in the scenes and discourse of the film Antichrist, mapping the semantic fields in their contrastive symbologies. In order to do so, a possible reading of the relations of the film in question will be outlined as a representation of Friedrich Nietzsche's ideas in the works The birth of tragedy and The dionysian vision of the world and as representation of Camille Paglia's ideas in the Sexual person. Thus, in the film Antichrist, the duplicity of the apollonian and dionysian elements and their unfolding through the above-mentioned works of Nietzsche will be highlighted, and the relations between feminine and masculine, beautiful nature and the daimonic nature of Paglia's above-mentioned work will be highlighted. Stands out, about everything, the importance of investigating the social structure present in and by language, be it film, literary, or everyday, in order to highlight the relationship between word and world.
\end{abstract}

Keywords: Languages. Apollonian and Dionysian. Female and Male. Beautiful nature and Daimonic nature.

Anticristo (Antichrist em inglês), filme de $2009,{ }^{2}$ do diretor e cineasta dinamarquês Lars von Trier $^{3}$ é uma experiência que pode causar certo desconforto aos espectadores, tanto

\footnotetext{
1 Autor. Licenciado em Letras Português pela Universidade Federal de Santa Maria. Mestre em Estudos Linguísticos pelo Programa de Pós-Graduação em Letras da Universidade Federal de Santa Maria. Educador linguoliterário. Professor pesquisador no projeto CADRELP - Núcleo de Capacitação em Desenvolvimento de Recursos em Ensino de Língua Portuguesa - do Centro de Artes e Letras da UFSM. Revisor linguístico instrucional no Núcleo de Educação a Distância do Colégio Técnico Industrial da UFSM.

2 "O Anticristo é um drama psicológico - um legítimo filme de terror interno. O casal interpretado por William Dafoe e Charlotte Gainsbourg sofre a morte de um filho em um acidente. A culpa e a depressão se instalam, em especial na mulher. Ela está sendo tratada no hospital, mas sendo o marido terapeuta, acha que pode cuidar sozinho do caso. Os dois vão para uma cabana isolada no meio da mata, confiantes em que a solidão e o
} 


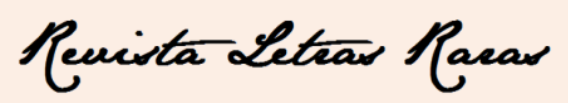

ISSN: 2317-2347 - Vol. 5, Ano 5, № 2 - 2016

no plano das cenas e imagens, do andamento e da composição narrativa fílmica, quanto no plano das simbolizações que permeiam toda a obra em questão. O filme é dividido em partes, são elas, respectivamente: Prólogo, Luto-Dor (O Caos Reina), Desespero (Feminicídio), Os Três Mendigos e Epílogo.

O entendimento do filme Anticristo como uma menção, ou como uma celebração do diretor Lars von Trier aos fundamentos de Nietzsche advém, em um primeiro instante, pelo título da obra cinematográfica, a qual faz referência a uma obra de Nietzsche ( $O$ Anticristo, ensaio de uma crítica ao Cristianismo). Porém, considera-se que o horizonte de fundamentação do conteúdo do filme de von Trier seja $O$ nascimento da tragédia e $A$ visão dionisíaca do mundo, o que será detalhado na linearidade deste trabalho.

Ademais, dos conhecimentos limitados (do autor desse ensaio) quanto às teorias fílmicas, o que se pode perspectivar é um estudo da semiologia no cinema nas suas motivações conotativas, em simbolizações não arbitrárias, e em simbolizações parciais ao alcance de noções de analogia com códigos culturais específicos, porém não evidentes a todos os espectadores.

Em Anticristo, o corpus temático parece ser motivado pelos elementos apolíneos e dionisíacos da obra $O$ nascimento da tragédia, de Nietzsche, portanto, decorrente de designação não arbitrária, constituindo-se como alegoria e não como símbolo. Entretanto, certos aspectos de Anticristo permanecem sob a luz do símbolo, uma vez que universais em sua compreensão (o corvo, por exemplo), mas os símbolos utilizados no filme em questão funcionam como elementos primários de uma compreensão metonímica para alegorias que dizem respeito ao apolíneo e ao dionisíaco em Nietzsche.

A figura do corvo aparece em duas cenas, na primeira, ele é utilizado como símbolo de mau presságio, uma vez que o seu grasnar faz com que a personagem masculina seja descoberta em um buraco pela personagem feminina. Posteriormente, o corvo é utilizado como símbolo de esperança, pois o seu grasnar faz com que a personagem masculina consiga encontrar uma ferramenta para livrar-se dos pesos de metal que estavam em sua perna.

enfrentamento da depressão poderão curar a dor, a culpa e o arrependimento. [...] Lars Von Trier parece querer tocar nas franjas do inconsciente, quer dizer, naquilo que não pode ser dito ou descrito. [...]Von Trier poderia ter colocado como epígrafe: uma obra para espíritos livres, pois só estes a entenderão" (ZANIN, 2009).

${ }^{3}$ Lars von Trier é conhecido pelos seus filmes de hiperrealismo (pautados em cenas consideradas por muitos, como violentas, seja no plano do real, seja no plano do simbólico, as quais pretendem criar significados e sentidos implícitos que devem ser resgatados pelo espectador). Ele lançou, em 1995, junto do também diretor de cinema, Thomas Vinterberg, um movimento chamado Dogma 95, o qual propunha-se a afastar as produções fílmicas dos grandes capitais de investimento, privilegiando elementos de conteúdo da história ao invés de elementos de efeitos especiais, por exemplo, em uma contraposição ao cinema comercial estadunidense.

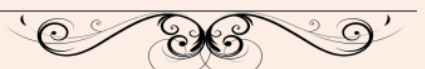




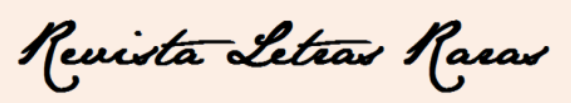

ISSN: 2317-2347 - Vol. 5, Ano 5, № 2 - 2016

Recorrendo ao pouco conhecimento teórico (do autor desse ensaio) acerca da arte cinematográfica, incide-se nas abreviações de um instrumento, passível de leituras corporificadas pelo papel do espectador como um organizador e mobilizador de representações sêmicas: "A semiologia do cinema é muitas vezes levada a colocar-se mais do lado do espectador do que do cineasta." (METZ, 2012, p. 121). Por isso, os significados alternantes em detrimento dos significantes mapeados no filme, passarão pela interpretação do espectador, munido de considerações um tanto quanto impressionistas, ou dirigidas somente aos aspectos acerca do apolíneo e do dionisíaco.

O Prólogo inicia-se com uma cena em preto e branco e em câmera lenta, apresentando o ato sexual explícito de um homem e de uma mulher, ao mesmo tempo em que um bebê, filho único do casal, a saber, na sequência temporal do filme, aproveita o descuido dos pais para abandonar o berço, caminhar pela casa, ver o ato sexual dos pais e subir em uma mesa próxima à janela aberta do quarto. A queda da janela coincide com o clímax sexual (orgasmo) dos pais. O primeiro par opositivo estabelece-se: vida e prazer (no ato sexual) e morte e dor (na queda da criança).

Todo o enquadramento fílmico dessas cenas sequenciais do Prólogo além, da apreensão ditada pelo uso do preto e branco e da câmera lenta, culminam, com a música Lascia ch'io Pianga (Deixe-me chorar), da ópera Rinaldo, de Handel, numa exposição do caráter elegíaco, ou de lamento pela morte, sendo cantada na voz de uma mulher, do que se pode depreender que o lamento feminino será evidenciado. Há de se mencionar que os próximos capítulos (Pain, Grief, Despair), ou partes do filme são pré-ditos com inscrições em três bonecos de chumbo que o bebê derruba ao subir na mesa, como mostra a imagem 1:

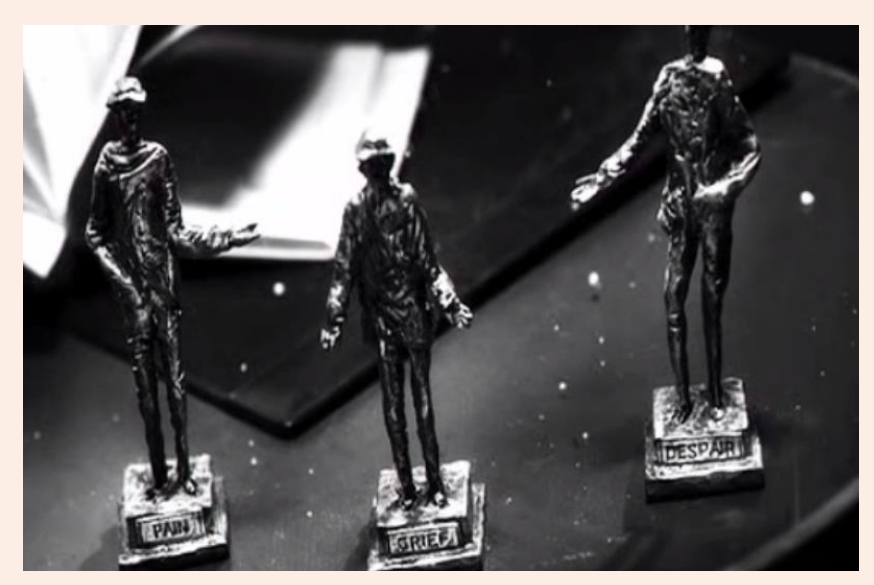

Imagem 1: Filme Anticristo (Lars von Trier, 2009). 


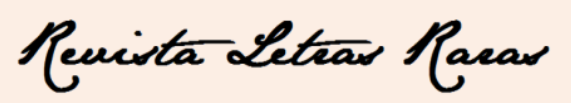

ISSN: 2317-2347 - Vol. 5, Ano 5, № 2 - 2016

No primeiro capítulo (Luto), a mãe da criança desmaia durante o enterro do filho e é amparada pelo marido. Já no hospital, a cena que se segue (imagem 2) é a de uma mulher que se sente culpada pela morte do filho e que em meio ao sofrimento, perde, inclusive, a noção temporal (embaralha a percepção da passagem do tempo cronológico e da passagem do tempo psicológico), o que parece remeter ao aspecto da natureza como elemento dionisíaco, uma vez que o natural não é regrado pelo tempo "mecanizado", linear, sequencial, ou seja, na natureza temos uma perspectiva de tempo como forma da sensibilidade, dos sujeitos e dos elementos naturais que organizam a vida num contínuo fluxo de estratagemas cíclicos:

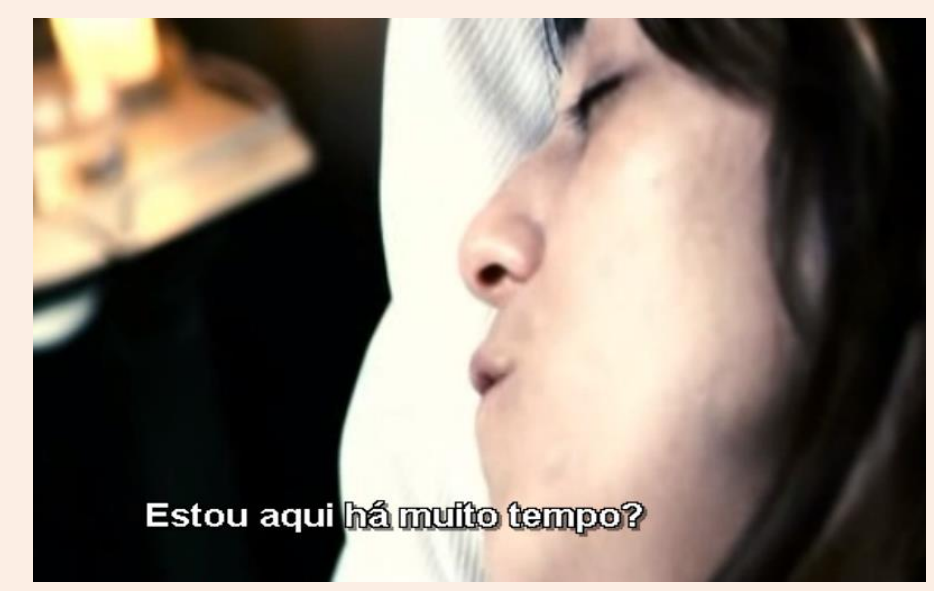

Imagem 2: Filme Anticristo (Lars von Trier, 2009).

O segundo par de oposição que se evidencia em Anticristo é a nomeação das personagens. Tanto a mulher como o homem são nomeados apenas como ELE e ELA, num esforço não racionalista, por isso dionisíaco, na necessidade de dissolução do indivíduo, ou seja, num esforço de não ordenação apolínea do ser humano, mas num esforço de homogeneização dionisíaca.

Porque o ato de nomear é apolíneo, uma vez que artificializa o ser humano primordial, o ser humano coletivo em seus desejos, através da aparência de um nome, que descolará todos os seres do coletivo para o particular, num reconhecimento de controle como dominação e da dominação como um fenômeno apolíneo sobre a natureza dionisíaca do homem preso à sua existencial material e caótica: "Nome e pessoa fazem parte da busca de forma do Ocidente, que insiste na identidade distinta dos objetos. Denominar é conhecer; conhecer é controlar." (PAGLIA, 1992, p. 16) 


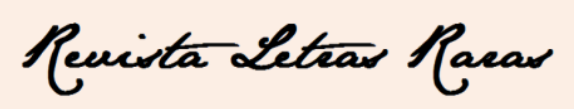

ISSN: 2317-2347 - Vol. 5, Ano 5, № 2 - 2016

O terceiro par de oposição a destacar-se em Anticristo é a tentativa dessa mulher de entregar-se ao luto pela morte do filho, aceitando o sofrimento enquanto característica humana, incontrolável, como força dionisíaca no reconhecimento do instinto natural, do saber-se e reconhecer-se enquanto ser humano; e a figura desse homem racional, tentando dar conta de algo que não compreende, tentando racionalizar através da ciência (psicanálise) os sentimentos de sua esposa. O masculino e o feminino começam a contrapor-se nas sucessivas conversas entre esposo e esposa e atingirão o seu ápice quando do contato do homem com a natureza (imagem 3).

Esse homem coloca-se enquanto sujeito e enquanto profissional (analista) disposto a "curar" a esposa, porque conhecedor das técnicas científicas e da subjetividade dela, mas desconsidera que está a tratar de um ser humano coletivo, imerso num conflito generalizante e totalizador de toda e qualquer pessoa.

Diante do sofrimento, o marido decide tratá-la e, ao questioná-la sobre o seu maior medo e não obter resposta, pergunta pelo lugar em que ela mais teme ir. Ao que a esposa fala da floresta, da cabana, lugar chamado de Éden, em que ela e o filho passaram o verão, e em que ela escrevera uma tese sobre feminicídio. Parece que o homem (o esposo) se orienta pela sua posição racional, na tentativa de apaziguar a irracionalidade feminina (da esposa) e conter o extravasamento de emoções desconfortáveis para ele. Pode-se também, observar que em querer dominar os sentimentos naturais da esposa, o homem tem uma atitude de defesa contra o seu feminino, o seu luto e a sua dor, como afirma Camille Paglia:

Freud diz: "O homem teme que sua força lhe seja tirada pela mulher, teme contaminar-se com a feminilidade dela e depois mostrar-se um fracote". A masculinidade tem de combater o efeminamento dia a dia. A mulher e a natureza estão sempre prontas para reduzir o homem a menino e bebê (PAGLIA, 1992, p. 37). 


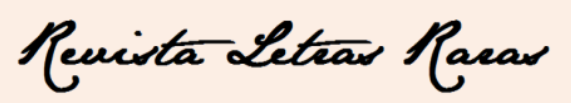

ISSN: 2317-2347 - Vol. 5, Ano 5, № 2 - 2016

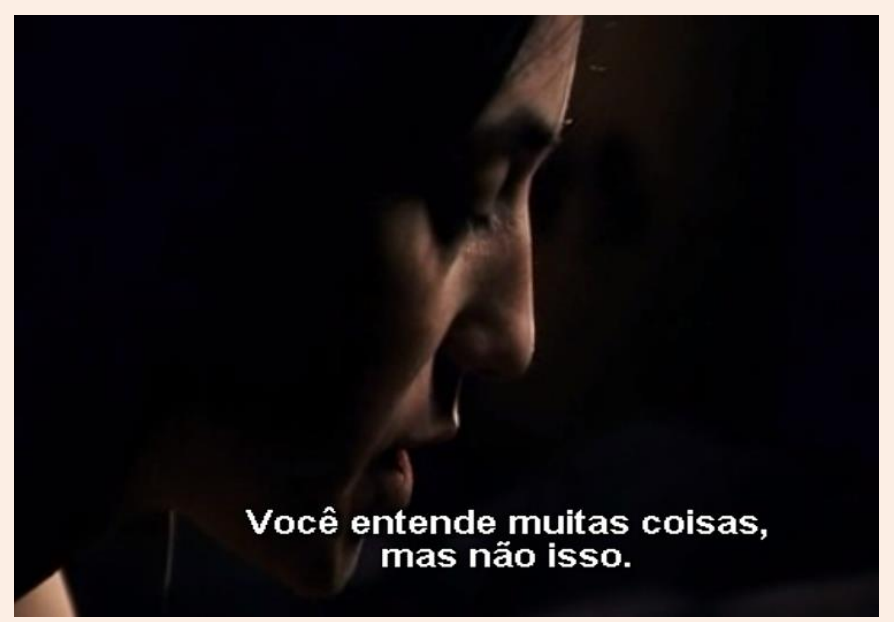

Imagem 3: Filme Anticristo (Lars von Trier, 2009).

Ainda no mesmo capítulo tem-se o par opositivo evidenciado por Paglia em Personas Sexuais, no contraste entre cultura e natureza, entre natureza bela e natureza daimônica. As personagens transferem-se de um espaço urbano, portanto, caracterizadamente civilizado, para um espaço natural (despido dos símbolos de civilidade), espaço esse, onde a racionalidade e a segurança do homem começam a ruir, porque em contato com a fluidez da natureza que desvela a desestabilização e a destruição das certezas, num movimento dionisíaco de totalização.

Tal totalização é pressuposta na cena em que o homem observa a natureza, bela e tranquila, na aparição de um cervo, que ao dar as costas a ele, exibe um feto morto saindo de suas entranhas (imagem 4). O apolíneo da aparência exigente de beleza é confrontado com o dionisíaco do término da vida e da aceitação do sofrimento como uma característica que gera o júbilo da existência:

Dizemos que a natureza é bela. Mas esse julgamento estético, que nem todos os povos têm partilhado, é outra formação de defesa, desgraçadamente inadequada para abranger a totalidade da natureza. O que é bonito na natureza se limita à fina película do globo sobre o qual nos amontoamos. É só arranhar essa película, que surgirá a feiura daimônica da natureza. Nossa concentração no belo é uma estratégia apolínea. As folhas e flores, os pássaros, as montanhas são um desenho à da colcha de retalhos pelo qual mapeamos o conhecido. [...] O dionisíaco não é nenhum piquenique. São as realidades ctônicas de que foge Apolo, o triturar da força subterrânea, o longo e lento sugar, a treva e a lama. É a desumanizante brutalidade da biologia e da geologia, o desperdício e derramamento de sangue darwinianos, a miséria e a podridão que temos de barrar da consciência, a fim de manter nossa integridade apolínea como pessoas. (PAGLIA, 1992, p. 17) 


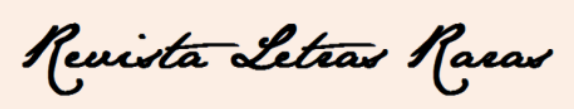

ISSN: 2317-2347 - Vol. 5, Ano 5, № 2 - 2016

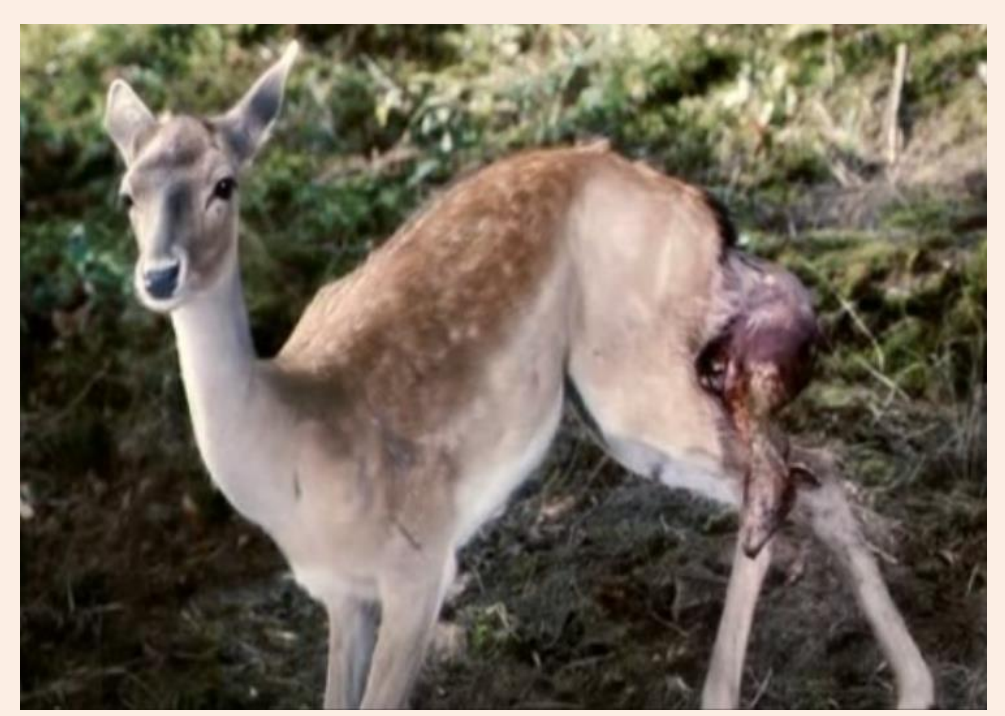

Imagem 4: Filme Anticristo (Lars von Trier, 2009).

Ou como afirma Nietzsche: "Devemos reconhecer que tudo aquilo que existe deve estar preparado para uma dolorosa submersão, vemo-nos obrigados a fitar os males da existência individual-e apesar disso não nos devemos deter.” (NIETZSCHE, 2006, p. 152)

Há uma cena (imagem 5) em que a mulher (ELA) observa a natureza em seu ciclo de vida, nada podendo modificar a essência da natureza, no absurdo da sobrevivência, senão aceitá-la, mesmo que com temor. Um filhote de pássaro cai de uma árvore e começa a ser atacado por formigas, as quais acabam perdendo seu alimento por um gavião que abocanha o filhote e o devora. E é com essa observação que a mulher, até então, temerosa, aceita a natureza em sua reconciliação com o homem.

A partir desse momento, a natureza parece estar na mulher e os seus desejos sexuais começam a tomar forma, revestidos de alívio, de ódio e de culpa, de histeria, de descompasso, de desmedida. É nessa perspectiva da natureza como continuum de energia natural através do despedaçamento e do esquartejamento que se observa a metamorfose de Dionísio, na desintegração e retorno, no ciclo de dissolução e liquidez (da natureza, da morte, do feminino, da maternidade); ciclo de vida e morte, da mãe terra não dividida, da mãe terra como UnoPrimordial, como materialidade terrestre, gerando e fazendo perecer.

Essa perspectiva, também é verificada na cena (imagem 6) em que o homem observa uma raposa a devorar suas próprias entranhas, numa alusão ao símbolo mítico do Ouroboros (serpente ou dragão que devora a própria cauda), numa evocação ao animal irracional como a natureza a seguir o seu movimento específico de autofecundação e de retorno, portanto,

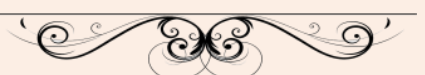




\section{Reuista Letear Raear}

ISSN: 2317-2347 - Vol. 5, Ano 5, № 2 - 2016

esforço dionisíaco da natureza acabando com a materialidade do corpo, em contraposição ao apolíneo racional do masculino (que observa, nomeia, que compreende apenas a superficialidade, ou a artificialidade da aparência):

[...] o esquartejamento é uma metáfora para as metamorfoses de Dioniso "em ventos e água, terra e estrelas, e nas gerações de plantas e animais". Dioniso, como Proteu, passa por todas as formas de ser, de alto a baixo. Humana, animal, vegetal, mineral: nenhuma tem status especial. Todas são igualadas e sacralizadas no continuum de energia natural. (PAGLIA, 1992, p. 98)

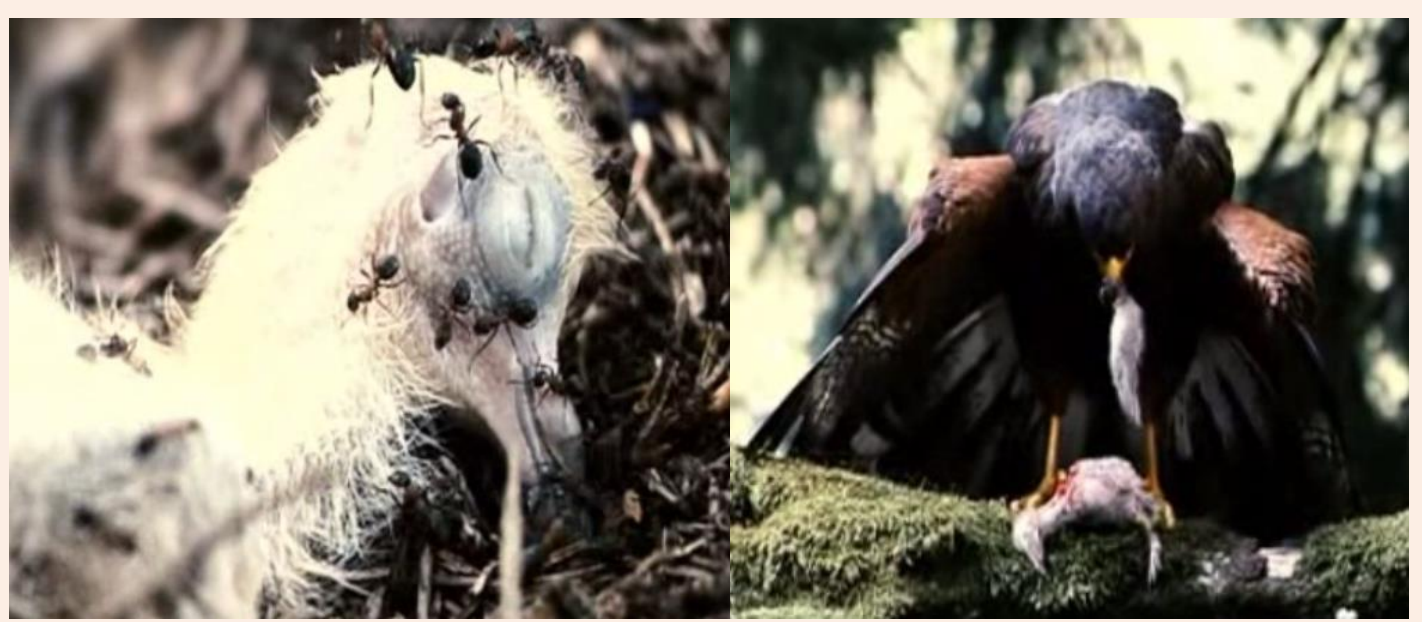

Imagem 5: Filme Anticristo (Lars von Trier, 2009).

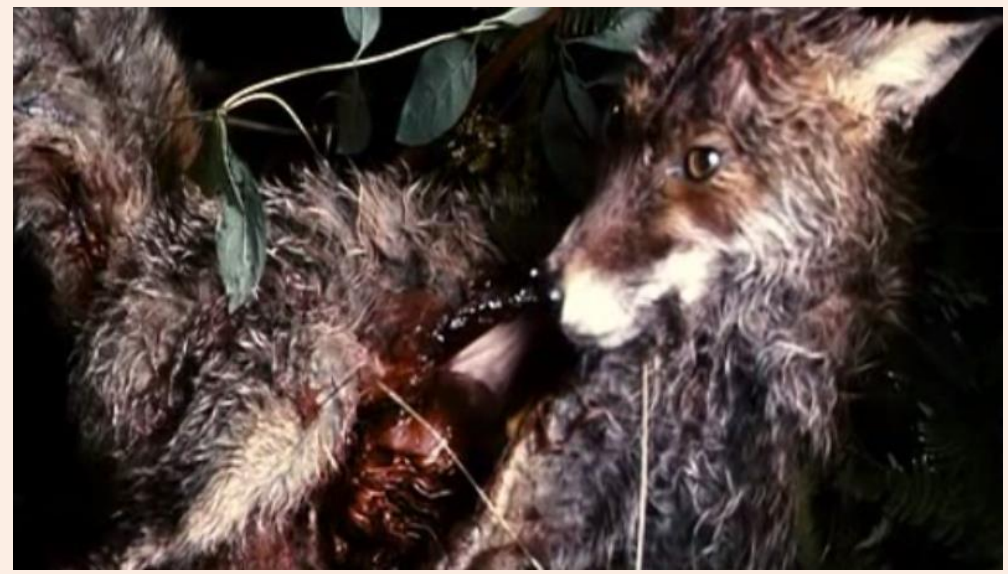

Imagem 6: Filme Anticristo (Lars von Trier, 2009).

Inicia-se o capítulo três (Desespero). Uma cena de sexo em meio à floresta (imagem 7), com várias mãos entrelaçadas nas raízes de uma árvore, significando o Uno-Primordial de Nietzsche, na fusão entre natureza e homem: 


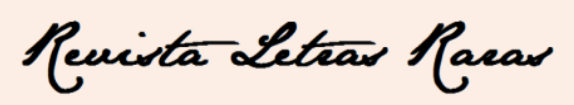

ISSN: 2317-2347 - Vol. 5, Ano 5, № 2 - 2016

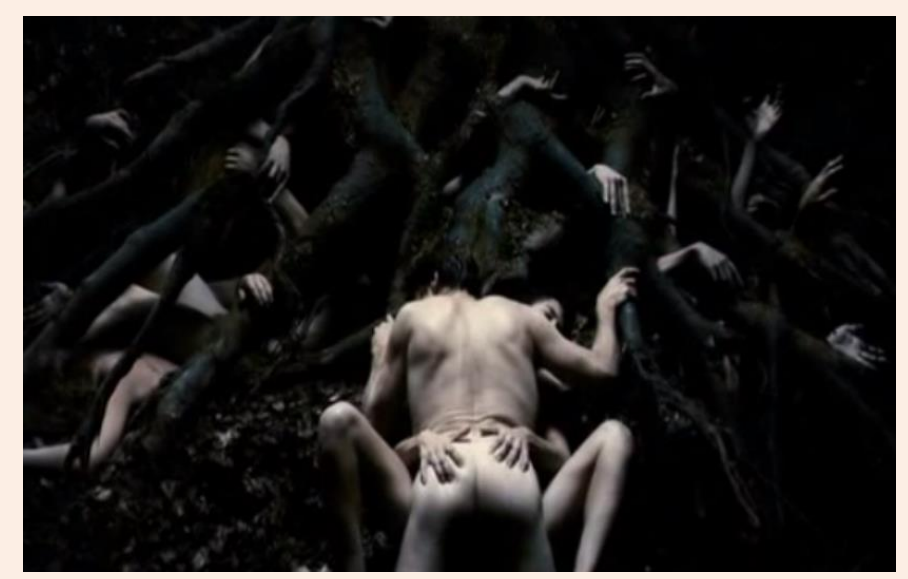

Imagem 7: Filme Anticristo (Lars von Trier, 2009).

$\mathrm{O}$ ato sexual em meio à natureza, numa alusão a um abraço (os braços a circundar o casal) parece demonstrar essa realidade ctônica da natureza, a união de natureza e homem, a fusão do homem às forças mais profundas da terra. Homem e mulher entregues a uma conjugação embriagada de seus corpos, assim como a natureza, abocanhando à racionalidade em detrimento das forças instintivas do corpo, ou seja, entregando-se ao natural, ao primitivo e relegando a racionalidade (tão marcadamente associada ao diferencial entre humanos e outras espécies de seres vivos).

$\mathrm{O}$ ato sexual como ênfase de morte, porque o orgasmo enquanto representante de uma pequena morte. $\mathrm{O}$ ato sexual é iniciado pela vontade da mulher, que está a masturbar-se próxima de uma árvore. Ao que o homem cede:

A imagem básica é da femme fatale, a mulher fatal para o homem. Quanto mais se repele a natureza no Ocidente, mais a femme fatale reaparece, como um retorno do reprimido. [...] O mito da vagina dentada (vagina dentata) dos índios norte americanos é uma transcrição hediondamente direta do poder feminino e do medo masculino. Metaforicamente, toda vagina tem dentes secretos, pois o macho sai com menos do que ao entrar. Castração física e espiritual é o perigo que todo homem corre no intercurso com uma mulher. O vampirismo latente da mulher não é uma aberração social, mas um desenvolvimento de sua função maternal, para a qual a natureza a equipou com exaustiva minuciosidade. Para o homem, todo ato sexual é um retorno à mãe, e uma capitulação a ela. Para os homens, o sexo é uma luta por identidade. No sexo, o homem é consumido e novamente liberado pelo poder dentado que o deu à luz, o dragão fêmea da natureza. (PAGLIA, 1992, p. 24) 


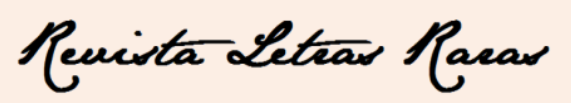

ISSN: 2317-2347 - Vol. 5, Ano 5, № 2 - 2016

Essa busca por uma identidade primordial do homem está relacionada ao único momento em que o mesmo consegue compreender o mistério do feminino e, portanto, atenuar seu racionalismo masculino. A tentativa de compreensão do feminino em sua esposa faz com que a personagem masculina de Anticristo acabe por encontrar as teses de feminicídio escritas pela esposa no verão passado, em que ela explica a natureza má das mulheres e o merecimento da morte das mesmas em detrimento das suas culpas.

O marido descobre que a sua esposa deformou os pés de seu filho e por isso decide deixá-la. Não querendo ser largada, a esposa prende o marido com barras de ferro em uma perna (talvez, uma metáfora do masculino preso à força feminina, quando da descoberta do instinto natural caótica do feminino-terra; talvez, uma metáfora da mãe-protetora, da mãe que não quer deixar seu filho à mercê do masculino, ao deformar os pés do menino para que ele permanecesse com ela).

É o início do caos absoluto do filme, quando a mulher afirma que tem melhorado, mas o homem não aceita a sua melhora e começa a agir estranhamente. Em uma cena do capítulo quatro (Os três mendigos), a mulher corta seu clitóris, o órgão do prazer feminino (imagem $8)$.

O que se pode depreender dessa cena é a mulher mutilando o seu próprio feminino, num esforço apolíneo pela racionalização desejada por seu marido, num esforço de punição pela maternidade.

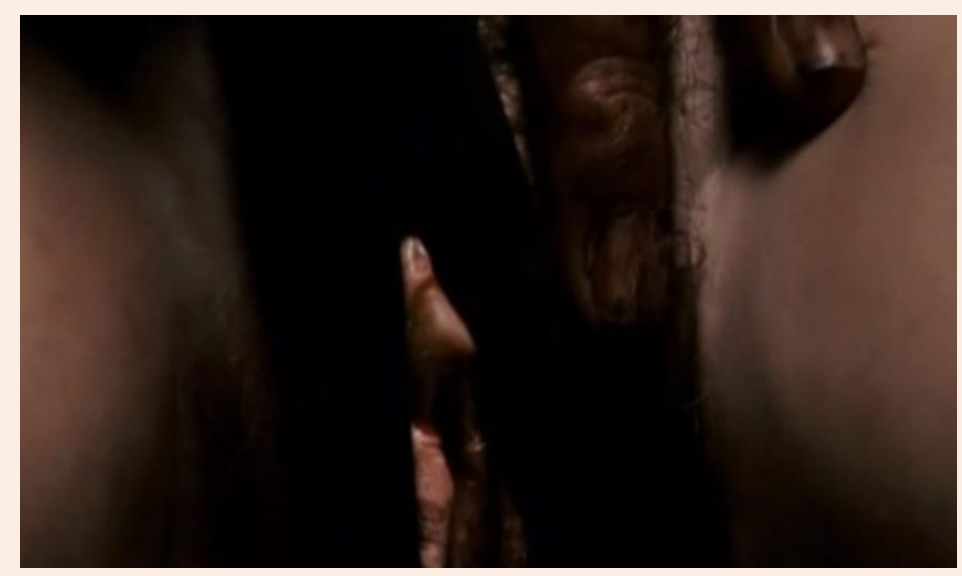

Imagem 8: Filme Anticristo (Lars von Trier, 2009).

A personagem feminina do filme é a personificação da natureza, da mãe que dá vida e que tira essa vida, tanto do seu filho, como do masculino em busca de uma identidade que não a maternal. Há no filme, uma imagem uterina (imagem 9), quando ELE esconde-se em um

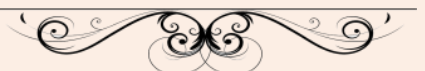




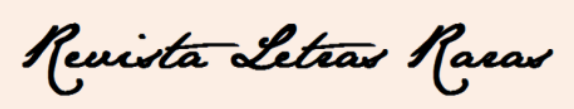

ISSN: 2317-2347 - Vol. 5, Ano 5, № 2 - 2016

buraco (uma toca) na terra, para fugir da sua esposa, já descontrolada. Parece que a fuga do feminino é impossível, que o feminino enquanto força natural, ctônica e desveladora da imagem violenta e destrutiva da essência humana faz parte de homens e de mulheres, ou seja, de toda a humanidade:

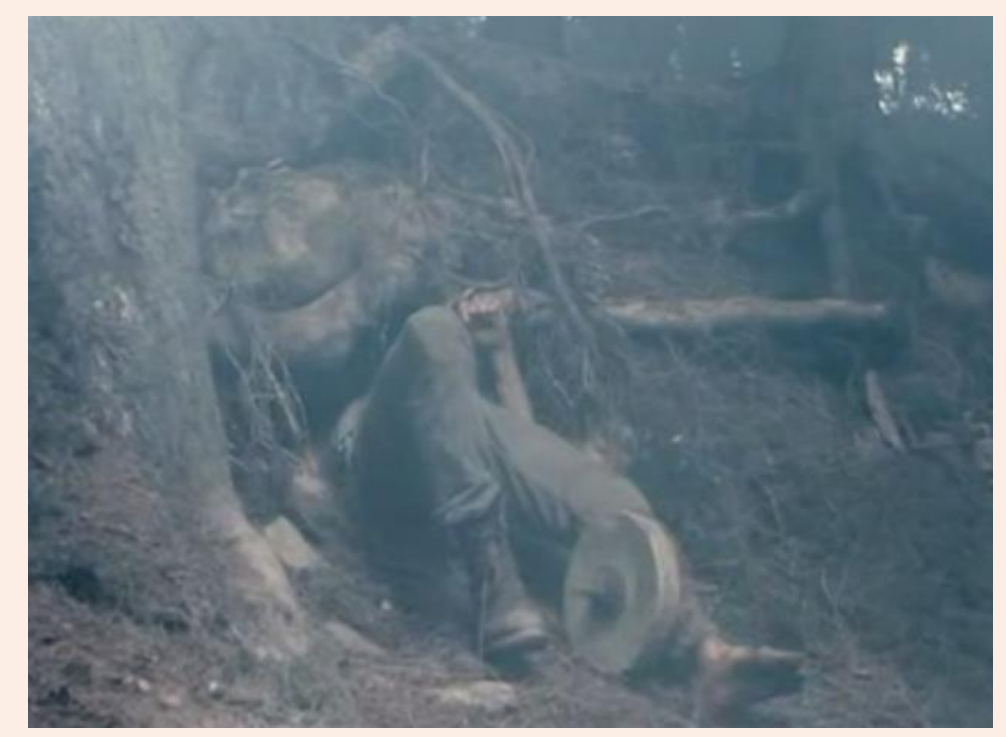

Imagem 9: Filme Anticristo (Lars von Trier, 2009).

Nesse último capítulo, o homem reúne todas as suas forças e estrangula e queima a sua esposa, numa morte simbólica do feminino, numa morte simbólica da natureza caótica e desestabilizadora do racional masculino, numa morte simbólica que também é nascimento, ou (re) nascimento, afinal, no Epílogo, último momento do filme, em câmera lenta, em preto e branco e com o retorno da música (da ópera) de Handel, o homem vê-se circundado pela invasão de inúmeras mulheres a subir e a descer montanhas (imagem 10).

Mulheres sem rosto, despidas de personas sociais, semelhantes em seu feminismo ctônico, em sua natureza daimônica (imagem 11), numa referência ao feminino, à natureza que está sempre retornando com sua bruteza a mostrar-nos o destino, a desmedida, o dionisíaco da embriaguez humana, demasiada humana, que dá vida, que mata, mas mata para dar sentido à existência. Uma multidão de mulheres que é a natureza chegando, arrastando sua força destruidora, fazendo o homem compreender a sua ligação com o natural, com o humano universal:

O principium individuationis é rompido em ambos os estados, o subjetivo desaparece inteiramente diante do poder irruptivo do humano-geral, do

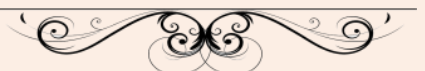




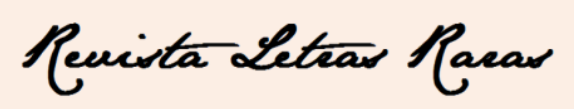

ISSN: 2317-2347 - Vol. 5, Ano 5, № 2 - 2016

natural universal. As festas de Dioniso não concluem tão só a ligação entre os homens, elas reconciliam também homem e natureza. Voluntariamente a terra traz os seus dons, as bestas mais selvagens aproximam-se pacificamente: coroado de flores, o carro de Dioniso é puxado por panteras e tigres. Todas as delimitações e separações de casta, que a necessidade e o arbítrio estabeleceram entre os homens, desaparecem: o escravo é homem livre, o nobre e o de baixa extração unem-se no mesmo coro báquico. Em multidões sempre crescentes o evangelho da "harmonia dos mundos" dança em rodopios de lugar para lugar: cantando e dançando expressa-se o homem como membro de uma comunidade ideal mais alta: ele desaprendeu a andar e a falar. (NIETZSCHE, 2006, p. 42)

Temos em Anticristo esses vários elementos ligados à terra, ao que não se pode dominar, ao homem enfrentando a si e caindo diante da natureza, porque essa é marcada pelo signo do desconhecimento. A racionalidade masculina é a cegueira que não permite ver Dionísio. A sensibilidade feminina é báquica, porque é a visão universal de uma natureza geradora, obscura, misteriosa e desmedida.

O primeiro passo dado pela mulher protagonista foi romper com a individuação apolínea e deixar vir à tona o perigo da vida, o perigo do reconhecimento dos instintos da natureza, que por si só desafiam a humanidade a compreender-se como tal, a saber-se indomável, a desestabilizar a aparência apolínea diante da natureza dionisíaca. Vivenciar a dor e a contradição de ser um humano, de não lutar contra esse humano calamitoso, pois somente assim é que se mostra a existência em sua verdadeira face e se pode renascer, a partir do tormento:

Nós mesmos somos realmente, por breves instantes, o ser primordial e sentimos o seu indomável desejo e prazer de existir, a luta, o tormento, a aniquilação das aparências se nos afiguram agora necessários, dada a pletora de incontáveis formas de existência a comprimir-se e a empurrar-se para entrar na vida, dada a exuberante fecundidade do mundo; (...) Apesar do medo e da compaixão, somos os ditosos viventes, não como indivíduos, porém como uno vivente, com cujo gozo procriador estamos fundidos. (NIETZSCHE, 2006, p.152) 


\section{Revista Leteas Raear}

ISSN: 2317-2347 - Vol. 5, Ano 5, № 2 - 2016

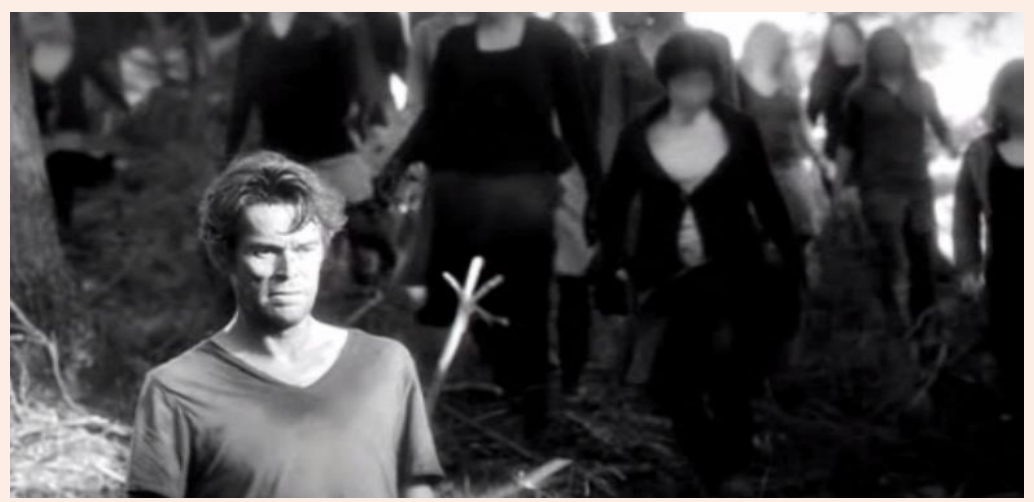

Imagem 10: Filme Anticristo (Lars von Trier, 2009).

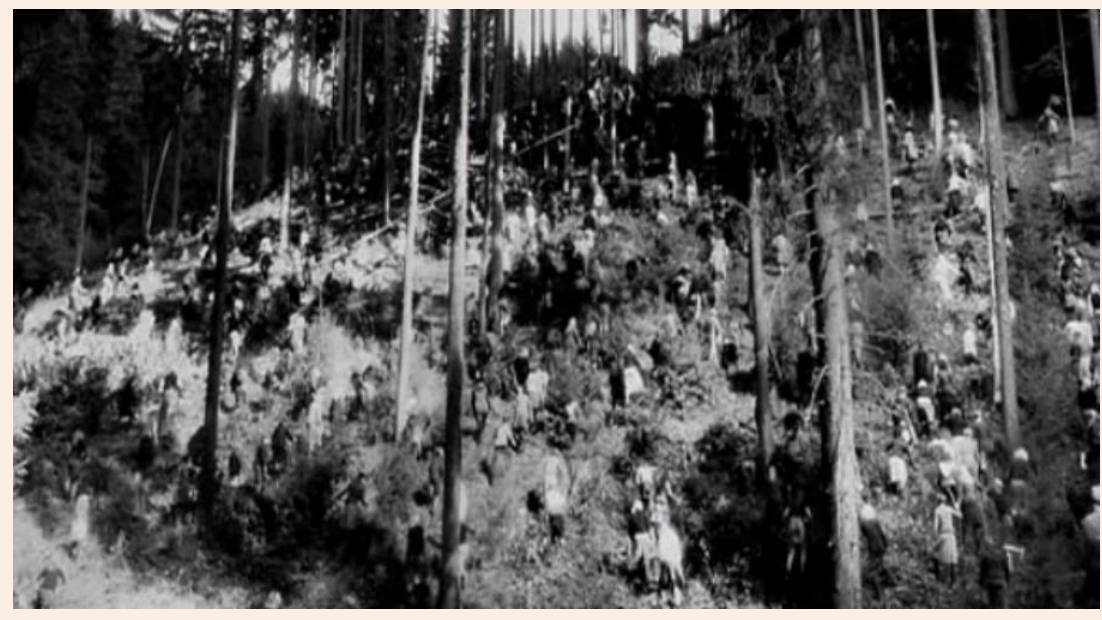

Imagem 11: Filme Anticristo (Lars von Trier, 2009).

Em resumo, esse ensaio propôs-se a perscrutar semioses ${ }^{4}$ do e no filme Anticristo, de Lars von Trier, para além da sua superfície verbovisual (a narrativa sobre um casal que, durante um ato sexual, não percebe que seu filho bebê atira-se por uma janela de um quarto), apresentando uma leitura possível para tal produção fílmica baseada na esquematização dos elementos apolíneos e dionisíacos e dos elementos feminino e masculino e natureza bela e natureza daimônica (presentes, respectivamente, nas obras de Nietzsche e de Paglia utilizadas como aporte teórico desse trabalho).

Dessarte, à guisa de conclusão, destaca-se que Anticristo tenta representar a conjunção racionalidade versus subjetividade, problematizando a relação íntima do feminino com a natureza (instintiva, fluída, libertadora), de modo a evidenciar, de alguma maneira, a dinâmica sociocultural de opressão ao feminino por meio de signos de insanidade e de irracionalidade.

\footnotetext{
${ }^{4}$ Semiose diz respeito à análise da ação e da atividade de signos (entendidos como aquilo que representa algo para alguém) dentro de um esfera de produção de sentidos em um dado objeto, segundo Charles Sanders Pierce (1995).
}

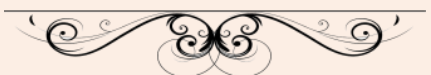




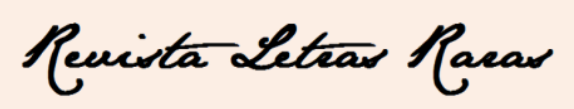

ISSN: 2317-2347 - Vol. 5, Ano 5, № 2 - 2016

Por que motivo os rostos "sem rostos" das mulheres que sobem a montanha no final do filme Anticristo?

\section{Referências}

ANTICRISTO. Direção: Lars von Trier. Intérpretes: Charlotte Gainsbourg, Willem Dafoe et al. Dinamarca: Califórnia Filmes, 2009. 1 DVD (110 min), son., color.

METZ, Christian. A significação no cinema. Tradução de Jean-Claude Bernardet. São Paulo: Perspectiva, 2012.

NIETZSCHE, Friedrich. O nascimento da tragédia. Tradução de J. Guinsburg. São Paulo: Companhia das Letras, 2006.

NIETZSCHE, Friedrich. A visão dionisíaca do mundo e outros textos de juventude. Tradução de Maria Cristina dos Santos de Souza e Marcos Sinésio Pereira Fernandes. Rio de Janeiro: UERJ, 2001.

ROSA, Maria Cecília Amaral de. Dicionário de símbolos: o alfabeto da linguagem interior. São Paulo: Editora Escala, 2009.

PAGLIA, Camille. Personas Sexuais: arte e decadência de Nefertite a Emily Dickinson. Tradução de Marcos Santarrita. São Paulo: Companhia das Letras, 1992.

PEIRCE, Charles Sanders. Semiótica. Tradução de José Teixeira Coelho Neto. São Paulo: Perspectiva, 1995.

XAVIER, Ismail. A experiência do cinema. Rio de Janeiro: Edições Graal, Embrafilme, 1983. ZANIN, Luiz. $O$ Anticristo: a dor $e$ o sexo. (2009). Disponível em: < http://cultura.estadao.com.br/blogs/luiz-zanin/o-anticristo-a-dor-e-o-sexo/>. Acesso em: 09 nov. 2016.

Recebi em: 02/09/2016

Aceito em: 30/09/2016 